\title{
Waders (Aves, Charadriiformes) in a Mediterranean remnant wetland: a year-round pilot study evidences contrasting patterns in diversity metrics
}

\author{
Corrado Battisti ${ }^{1}$, Aldo Boano ${ }^{2}$, Michele Cento ${ }^{2}$, Amedeo Circosta ${ }^{1}$, \\ Sergio Muratore ${ }^{2}$
}

\begin{abstract}
Around a yearly cycle (August 2011 - July 2012), we studied the assemblages of waders (Aves Charadriiformes) occurring in a Mediterranean remnant wetland, obtaining a set of diversity metrics. Mean total abundance shows a complementary pattern when compared to species richness and diversity: the highest values of mean total abundance were observed in December-January, due to high dominance of only one very abundant and gregarious species (the lapwing Vanellus vanellus). On the contrary, in this period, species richness and diversity showed the lowest values. These last metrics were highest in values during the April-September period when a large number of species of conservation concern utilize muddy areas as trophic and stop-over sites, due to the seasonal water stress. The highest values in species turnover index were observed between December-January and February-March when passage migrants (high richness, low abundance) substitute the wintering species (low richness, high abundance). Our data highlight that, in Mediterranean remnant wetlands, strategies should be addressed to increase the muddy suitable areas in the April-September period in order to maximize species richness and diversity. In fact, in these months these habitats host pre- and post-breeding migrant waders of conservation concern.
\end{abstract}

Key words: Abundance, species richness, diversity, species turnover, Vanellus vanellus.

Riassunto - Limicoli (Aves, Charadriiformes) in una zona umida mediterranea: uno studio pilota annuale evidenzia andamenti contrastanti nelle metriche di diversità.

Durante il ciclo annuale agosto 2011 - luglio 2012 sono state studiate le comunità di caradriformi (Aves Charadriiformes) presenti in una zona umida mediterranea, ottenendo una serie di metriche di diversità. L'abbondanza totale media mostra un andamento complementare se confrontata con la ricchezza di specie e la diversità: i valori più alti dell'abbondanza media totale sono stati rilevati in dicembre-gennaio, a causa della elevata dominanza di una sola specie molto abbondante e

\footnotetext{
1 "Torre Flavia" LTER (Long Term Ecological Research) Station, Provincia di Roma, Servizio aree protette - parchi regionali, via Tiburtina 691, Roma, Italia.

E-mail: c.battisti@cittametropolitanaroma.gov.it

${ }^{2}$ SROPU, Stazione Romana Osservazione e Protezione Uccelli, via Britannia 36, Rome, Italia.

E-mails: aboano@hotmail.it, acircosta@tiscali.it,michi.100@ libero.it, sergio_muratore@yahoo.it

*Corresponding author:c.battisti@cittametropolitanaroma.gov.it

(C) 2015 Corrado Battisti, Aldo Boano, Michele Cento,

Amedeo Circosta, Sergio Muratore
}

Received: September 30, 2014

Accepted for publication: November 16, 2014 gregaria (pavoncella Vanellus vanellus). Al contrario in questo periodo ricchezza e diversità hanno mostrato i valori più bassi. Queste ultime metriche hanno mostrato i valori più elevati nel periodo aprile-settembre, quando un gran numero di specie di interesse conservazionistico utilizzano le ripe fangose come sito trofico e di stop-over, anche a causa dello stress idrico stagionale. I valori più alti dell'indice di turnover sono stati osservati tra dicembre-gennaio e febbraio-marzo, quando le specie di passo migratorio (con alta ricchezza e bassa abbondanza) sostituiscono le specie svernanti (con bassa ricchezza e alta abbondanza) Questi dati sottolineano come, in aree umide residuali del Mediterraneo, le strategie di conservazione devono essere indirizzate verso un incremento delle ripe fangose idonee nel periodo aprile-settembre, al fine di massimizzare la ricchezza di specie e la diversità. Infatti, proprio in questi mesi questi habitat ospitano caradriformi di interesse conservazionistico in migrazione pre- e post-riproduttiva.

Parole chiave: Abbondanza, ricchezza di specie, diversità, turnover di specie, Vanellus vanellus.

\section{INTRODUCTION}

Mediterranean wetlands host strategic habitats suitable as stopover sites for waders (order Charadriiformes, suborders Scolopaci and Charadrii) (Blondel \& Aronson, 1999; Mitsch \& Gosselink, 2000). Due to seasonal water level fluctuations these habitats host many individuals of these groups during the pre- and post-breeding migration (Brönmark \& Hansson, 2005; van der Walk, 2006; Scarton et al., 2013). Especially in small remnant wetlands, in wintering and migration periods waders may occur with high abundance due also to the limited suitable habitats available in the fragmented surrounding areas (crowding effect; Debinski \& Holt, 2000), unlike fragmentation-sensitive breeding species that decline in their number (Celada \& Bogliani, 1993; Martìnez-Vilalta et al., 2002; Poulin et al., 2002; Abed, 2007; Benassi et al., 2009; Scarton et al., 2013).

In Mediterranean areas a high number of wader species are of high conservation concern (i.e. they are included in Red Lists and in the Annex 1 of 79/409/CEE "Birds" Directive; BirdLife International, 2004) and many researches on demography, ecology and behaviour of single species or guilds have been carried out (e.g. Gillings et al., 2005; Lourenço et al., 2008; Trotta, 2012). Although several studies have been carried out on water-related species (for Tyrrhenian wetlands, see Biondi et al., 1990; Angelici \& Brunelli, 2012), they have been often limited in time (e.g., Serra et al., 1992; Nankinov et al., 1996). 
Therefore, little research has been focused on the yearly patterns of diversity metrics applied to the whole wader community, here considered as a ecological assemblage (sensu Magurran, 2004). Studies on this topic have strategic implication in wetland conservation since waders are an assemblage of conservation concern per se and as indicators of the state of wet ecosystems (Ryan, 2013).

Abundance, frequency, species richness and diversity are the univariate metrics most used in field studies (Magurran, 2004; Magurran \& McGill, 2011). These metrics are differently sensitive to changes in environmental or human-induced parameters (e.g., linked to disturbances; Dornelas et al., 2011). Therefore, the knowledge about long term period metrics gives useful information for strategies in wetland management.

The aim of this pilot study is to provide and compare data on the diversity metrics (mean total abundance, mean species richness and Shannon-Wiener diversity) around a yearly cycle for a specific group of water-related birds (waders: Scolopaci and Charadrii) occurring in a Mediterranean remnant wetland of the Tyrrhenian central Italy.

\section{MATERIAL AND METHODS}

\section{Study area}

The study area is the Torre Flavia wetland $\left(41^{\circ} 58^{\prime} \mathrm{N}\right.$; $12^{\circ} 03^{\prime} \mathrm{E}$; a Special Area of Conservation according to the EU Directives 79/409 and 147/2009/CE; hereafter TFW), a nature reserve consisting of 40 ha of coastal wetland located on the Tyrrhenian seashore (Central Italy). From a bioclimatic point of view the area belongs to the mesoMediterranean xeric region (Tomaselli et al., 1973; Blasi $\&$ Michetti, 2005). It represents a relict of a larger wetland, partially drained and transformed in the last fifty years, where water is mainly of rain and sea storm origin and flow from surrounding areas is scarce. Water depth varies with the seasons: from October to March the flood level reaches the maximum value $(70 \mathrm{~cm})$, while from June to October it is reduced to form some areas of muddy soil or shallow ponds (Battisti et al., 2006; Zacchei et al., 2011; seasonally flooded wetland sensu Cowardin et al., 1979).

The study area shows a specific, semi-natural patchiness, composed of different patches: reed beds, dominated by Phragmites australis (Cav.) Trin ex Steudel, which are cut off by water basins, such as ponds and channels used for mullet fish farming, as Mugil cephalus L., Liza ramada (Risso), Liza saliens (Risso); rush flooded meadows dominated by Juncus sp. and Carex sp. (Juncetalia maritimi: habitat type of conservation concern; 92/43 "Habitat" CEE directive); coastal dunes (Battisti, 2006). The surrounding matrix is a mosaic of cultivated and uncultivated lands, adjacent to human settlements, and includes a seasonally flooded pasture moderately grazed by horses.

Therefore, at landscape scale, the study area can be considered a fine-grained disturbance mosaic (Hobbs \& Huenneke, 1992) within a man-disturbed matrix (i.e. agricultural and urban; Battisti et al., 2008; Amori \& Battisti, 2008). Land cover use shows various level of naturalness, from high (reed beds and rush meadows), to medium (pasture and uncultivated lands) and low or absent (croplands and urban areas). Further data from this area are available in Arena et al. (2011), Redolfi De Zan et al. (2011), Angelici et al. (2012), Santoro et al. (2012).

\section{Data collection and analyses}

Waders were counted at individual level from sampling points located near suitable muddy sites internal to TFW (complete count from fixed points: Bibby et $a l ., 1992)$. In the study area we located 5 fixed counting points. In each point we carried out a number of independent sampling sessions (lasting about one hour each visit) over a 12 months period (from August 2011 to July 2012) obtaining a number of waders (individuals and species) per visit. Totally, we carried out 44 visits, randomly distributed in day-time (07.00-16.00) and seasonally (total amount: 2180 minutes of sampling). The overall sampled data corresponded to the sum of the data obtained from the independent sampling sessions carried out in the 5 fixed points.

To obtain averaged values from a representative number of visits, data were pooled in bimonthly periods from August-September 2011 to June-July 2012. Since the number of visits (and sessions) was different in different bimonthly periods, data were normalized, obtaining relative frequencies and average values of abundance and richness. Therefore, for each period we obtained: i) the relative frequency of each species $\left(\mathrm{Fr}_{\mathrm{i}}\right)$; ii) the mean species richness (S mean), calculated as an average value of recorded species in the bimonthly visits; iii) the mean total abundance (Abb mean) for all the species, calculated as an average value of individuals recorded in bimonthly visits; iv) the Shannon-Wiener diversity index $\left(\mathrm{H}^{\prime}\right)$, calculated as $\mathrm{H}^{\prime}=-\Sigma \mathrm{Fr}_{i} \ln \mathrm{Fr}_{i}$ (Shannon \& Weaver, 1963; review in Magurran, 2004).

Moreover, comparing the species assemblages between bimonthly periods we obtained a temporal turnover index (Brown \& Kodric-Brown, 1977) calculated as: $t=(b+c) /\left(S_{1}+S_{2}\right)$, where: $b=$ the number of species present only in the first bimonthly period, $\mathrm{c}=$ the number of species present only in the second bimonthly period, $\mathrm{S}_{1}=$ the total number of species in the first bimonthly period, $\mathrm{S}_{2}=$ the total number of species in the second bimonthly period.

\section{Statistical analyses}

To test the differences among bimonthly average values in abundance we performed a Kruskal-Wallis nonparametric test (Dytham, 2011) with SPSS 15.0 software for Windows (SPSS Inc., 2006). Alfa value was set to 0.05 . Where possible, for data reliability we followed Battisti et al. (2014).

\section{RESULTS}

Altogether, we sampled 368 individuals belonging to 22 waders species (Tab. 1). Over the year, six species were dominant $(\mathrm{Fr}>0.05)$ : Vanellus vanellus (in late autumn-winter), Gallinago gallinago (from late summer to autumn), Philomachus pugnax (in spring-summer), Charadrius dubius (spring-autumn), Himantopus himantopus (in spring-summer), Tringa glareola (in spring and autumn). 
Tab. 1 - List of the wader species subdivided for bimonthly periods around a yearly cycle (from AugustSeptember 2011 to June-July 2012). $\mathrm{Fr}_{\text {i }}=$ relative frequency; $\mathrm{N}=$ total number of occurrences. In bold, the dominant species $\left(\mathrm{Fr}_{\mathrm{i}}>0.05\right)$. Number of visits for bimonthly periods and in total are reported. / Lista dei caradriformi suddivisi per periodi bimestrali su un ciclo annuale (da agosto-settembre 2011 a giugno-luglio 2012). $\mathrm{Fr}_{\mathrm{i}}=$ frequenza relativa; $\mathrm{N}=$ numero totale di ricorrenze. In grassetto, le specie dominanti $\left(\mathrm{Fr}_{\mathrm{i}}>0.05\right)$. È riportato anche il numero di visite per bimestre e totale.

\begin{tabular}{|c|c|c|c|c|c|c|c|c|}
\hline & Aug-Sep & Oct-Nov & Dec-Jan & Feb-Mar & Apr-May & Jun-Jul & & \\
\hline Visits & 14 & 10 & 4 & 6 & 4 & 6 & 44 & \\
\hline Species & $\mathrm{Fr}_{\mathrm{i}}$ & $\mathrm{Fr}_{\mathrm{i}}$ & $\mathrm{Fr}_{\mathrm{i}}$ & $\mathrm{Fr}_{\mathrm{i}}$ & $\mathrm{Fr}_{\mathrm{i}}$ & $\mathrm{Fr}_{\mathrm{i}}$ & $\mathrm{N}$ & $\mathrm{Fr}_{\mathrm{i}}$ \\
\hline Himantopus himantopus & 0 & 0 & 0 & 0 & 0.278 & 0.222 & 21 & 0.057 \\
\hline Recurvirostra avosetta & 0 & 0.038 & 0 & 0 & 0 & 0 & 2 & 0.005 \\
\hline Burhinus oedicnemus & 0 & 0 & 0 & 0.065 & 0 & 0 & 3 & 0.008 \\
\hline Charadrius dubius & 0.060 & 0 & 0 & 0.130 & 0.167 & 0.222 & 25 & 0.068 \\
\hline Charadrius hiaticula & 0.010 & 0 & 0 & 0 & 0.056 & 0 & 4 & 0.011 \\
\hline Charadrius alexandrinus & 0 & 0 & 0 & 0 & 0 & 0.037 & 1 & 0.003 \\
\hline Pluvialis apricaria & 0.010 & 0 & 0 & 0 & 0 & 0 & 1 & 0.003 \\
\hline Pluvialis squatarola & 0 & 0 & 0.008 & 0 & 0 & 0 & 1 & 0.003 \\
\hline Vanellus vanellus & 0 & 0.113 & 0.919 & 0 & 0 & 0 & 119 & 0.323 \\
\hline Calidris minuta & 0.010 & 0 & 0 & 0 & 0.019 & 0 & 2 & 0.005 \\
\hline Calidris ferruginea & 0 & 0 & 0 & 0 & 0.056 & 0.148 & 7 & 0.019 \\
\hline Calidris alpina & 0.060 & 0 & 0 & 0.022 & 0 & 0 & 5 & 0.014 \\
\hline Philomachus pugnax & 0.030 & 0.019 & 0 & 0.565 & 0.222 & 0.074 & 43 & 0.117 \\
\hline Gallinago gallinago & 0.210 & 0.604 & 0.073 & 0.043 & 0.019 & 0 & 59 & 0.160 \\
\hline Numenius phaeopus & 0 & 0 & 0 & 0.065 & 0 & 0 & 3 & 0.008 \\
\hline Actitis hypoleucos & 0.170 & 0 & 0 & 0 & 0.019 & 0.037 & 14 & 0.038 \\
\hline Tringa ochropus & 0.010 & 0 & 0 & 0 & 0.019 & 0.074 & 4 & 0.011 \\
\hline Tringa erythropus & 0.060 & 0.132 & 0 & 0 & 0 & 0 & 11 & 0.030 \\
\hline Tringa nebularia & 0.100 & 0.038 & 0 & 0.022 & 0 & 0 & 10 & 0.027 \\
\hline Tringa stagnatilis & 0 & 0 & 0 & 0.022 & 0.056 & 0 & 4 & 0.011 \\
\hline Tringa glareola & 0.260 & 0 & 0 & 0 & 0.056 & 0 & 21 & 0.057 \\
\hline Tringa totanus & 0 & 0 & 0 & 0.022 & 0.037 & 0.185 & 8 & 0.022 \\
\hline$N$ & 70 & 50 & 123 & 44 & 54 & 27 & 368 & 1 \\
\hline
\end{tabular}

We observed a bimodal pattern in mean abundance with two peaks: in December-January and secondarily in April-May (Tab. 2, Fig. 1). Nevertheless, the differences among averaged values are not significant $\left(\chi^{2}=10.419\right.$; $\mathrm{P}=0.064$; Kruskal-Wallis test). The high value in winter was due to high dominance of lapwings (Vanellus vanellus).

Mean species richness showed the highest value in April-May and secondarily in August-September. Diffe- rences among values are significant among bimonthly periods $\left(\chi^{2}=12.493 ; \mathrm{P}=0.029 ;\right.$ Kruskal-Wallis test $)$.

Shannon-Wiener diversity index showed a maximum in April-May and in August-September, and a minimum in December-January (Tab. 2, Fig. 1).

The highest value in species turnover index was observed between the December-January and FebruaryMarch bimonthly periods ( $\mathrm{t}=0.909)$, the lowest between the April-May and June-July $(\mathrm{t}=0.3)$. 


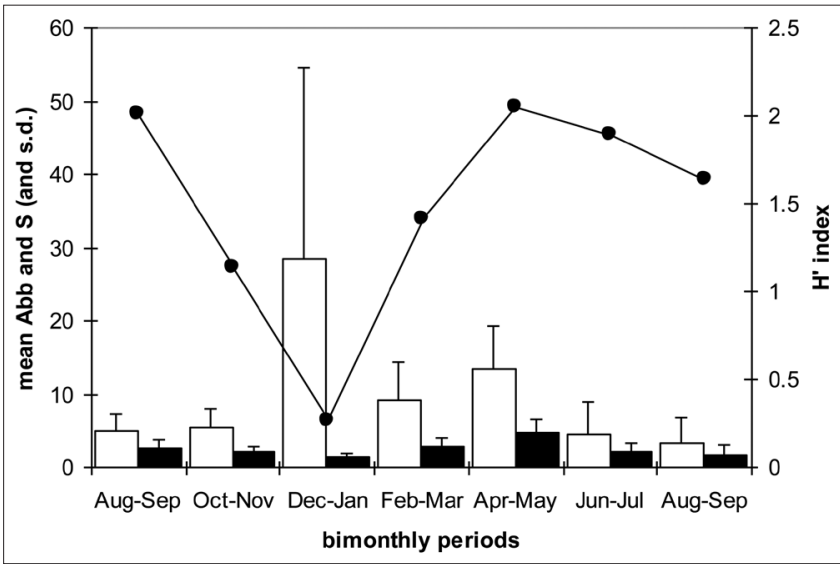

Fig. 1 - Yearly pattern of diversity metrics in Torre Flavia wetland (central Italy). Y axis (left): mean Abb $=$ mean total abundance $( \pm \mathrm{SD}$; white columns); mean $\mathrm{S}=$ mean species richness ( $\pm \mathrm{SD}$; black columns); (right): $\mathrm{H}^{\prime}$ index $=$ Shannon-Wiener diversity index (black point and continuous line). / Andamento annuale di metriche di diversità nella Palude di Torre Flavia (Italia centrale). Asse Y (sinistra): mean Abb = abbondanza totale media ( $\pm \mathrm{SD}$; colonne bianche); mean $\mathrm{S}=$ ricchezza specifica media $\left( \pm \mathrm{SD}\right.$; colonne nere); $($ destra $)$ : $\mathrm{H}^{\prime}$ index $=$ indice di diversità di Shannon-Wiener (punti scuri e linea continua).

Tab. 2 - Diversity uni-variate metrics of waders in Torre Flavia wetland subdivided for different bimonthly periods ( $n=$ number of visits). Between each pair of bimonthly periods the value of turnover index $t$ is also reported. For abbreviations, see Methods. / Metriche uni-variate di diversità di caradriformi nella Palude di Torre Flavia suddivise per periodi bimestrali ( $\mathrm{n}=$ numero di visite). E riportato anche il valore dell'indice di turnover $\mathrm{t}$ tra coppie di bimestri; mean $\mathrm{Abb}=$ abbondanza totale media $( \pm \mathrm{SD})$; mean $\mathrm{S}=$ ricchezza specifica media $( \pm \mathrm{SD})$; $\mathrm{H}^{\prime}=$ =indice di diversità di Shannon-Wiener; $\mathrm{t}=$ =indice di turnover (vedi Metodi).

\begin{tabular}{|c|c|c|c|}
\hline $\begin{array}{l}\text { Bimonthly } \\
\text { period }\end{array}$ & $\begin{array}{l}\text { mean Abb } \\
( \pm \text { s.d. })\end{array}$ & $\begin{array}{l}\text { mean S } \\
( \pm \text { s.d. })\end{array}$ & $\mathbf{H}^{\prime}$ \\
\hline Aug-Sep $(n=14)$ & $5( \pm 2.24)$ & $2.64( \pm 1.17)$ & 2.005 \\
\hline \multicolumn{4}{|c|}{$\mathrm{t}=0.556$} \\
\hline Oct-Nov $(n=10)$ & $5.3( \pm 2.69)$ & $2.1( \pm 0.83)$ & 1.141 \\
\hline \multicolumn{4}{|c|}{$\mathrm{t}=0.625$} \\
\hline Dec-Jan $(n=4)$ & $28.5( \pm 26.2)$ & $1.5( \pm 0.5)$ & 0.269 \\
\hline \multicolumn{4}{|c|}{$\mathrm{t}=0.909$} \\
\hline Feb-Mar $(n=6)$ & $9.17( \pm 5.21)$ & $2.83( \pm 1.07)$ & 1.414 \\
\hline \multicolumn{4}{|c|}{$\mathrm{t}=0.571$} \\
\hline Apr-May $(\mathrm{n}=4)$ & $13.5( \pm 5.9)$ & $4.74( \pm 1.92)$ & 2.049 \\
\hline \multicolumn{4}{|c|}{$\mathrm{t}=0.300$} \\
\hline Jun-Jul $(\mathrm{n}=6)$ & $4.5( \pm 4.5)$ & $2.2( \pm 1.1)$ & 1.893 \\
\hline \multicolumn{4}{|c|}{$t=0.667$} \\
\hline
\end{tabular}

\section{DISCUSSION}

Our data confirm the role of wetlands as trophic and stop-over sites for migrant and breeder waders especially during the spring (in April-May: highest mean species richness; Blondel \& Aronson, 1999; Mitsch \& Gosselink, 2000; Goutner et al., 2005; for central Italy, see also Angelici \& Brunelli, 2012). However, from spring to late summer (April-September) the wader diversity showed high values. During spring and summer the TFW and many other Mediterranean wetlands are characterized by water stress with a large availability of muddy areas of high trophic value for these species that are mainly migrants and use these areas as stop-over sites (Zacchei et al., 2011). In this sense the water stress, known as a selective seasonal disturbance for many water-related species (Battisti et al., 2004; Battisti et al., 2006; Redolfi De Zan et al., 2011), may be considered an opportunity for these specialized species (for a review on the species-specific concepts of stress, disturbance and opportunity see Barrett et al., 1976; Sousa, 1984; Petraitis et al., 1989; Brawn et al., 2001).

Mean total abundance shows a complementary pattern when compared to species richness and diversity. High value of mean abundance in winter (DecemberJanuary) was due to the high abundance of lapwings, a gregarious wintering species that in this period occurs in flooded areas and pastures (Kirby, 1997; Gillings et al., 2005; Trotta, 2012). The high dominance $(>0.9)$ of this species and the low number of species detected (three) cause a strong decrease of the diversity index in this period. We did not observe a significant change among the mean abundance values during the yearly cycle: this is due to a high data dispersion (i.e. high standard deviation: see Fig. 1) in December-January because of the high variability in visit-by-visit numbers of gregarious flocks of lapwings.

The abrupt change in mean abundance and diversity between December-January (when only three wintering species occur, one of them strongly dominant) and February-March (when the spring passage migrants arrive) has been highlighted by the high species turnover observed between these two periods. This last index shows the lowest values in spring and summer when this assemblage is more diverse and homogeneous.

Data from this pilot study should be confirmed from further studies on a more wide time span (e.g. interannual: see, for example, Saunders \& Derebeira, 1986) and with a more balanced and representative sample. However, although preliminary, they may have implications for management strategies in patchy wetlands where suitable muddy areas are available for waders (see also Finlayson, 1992). Indeed, strategies promoted by wetland practitioners should be addressed to increase the suitable muddy areas in the April-September period, when a large number of waders occur during the migratory pass, in order to increase richness and diversity of these rare and declining species of conservation concern (e.g. included in Annex 1 of 79/409/CEE and 147/2009/CE "Birds" Directives: BirdLife International, 2004). 


\section{Acknowledgements}

We would like to thank: Fulvio Fraticelli (SROPU Stazione Romana Osservazione e Protezione Uccelli) and Riccardo Molajoli (Gruppo Romano Birdwatching) for their help on conceiving this work; Stefano Guidotti and Davide Maglia ("Amici di Torre Flavia") for participating in the data collection; Dario Capizzi (ARP - Park Regional Agency, Lazio) for his suggestions. We also thank Sandra Wyatt for revising the English text. An anonymous reviewer have largely improved a first draft of the manuscript.

\section{REFERENCES}

Abed J.M., 2007 - Status of water birds in restored Southern Iraqi marshes. Marsh Bulletin, 2: 64-79

Amori G. \& Battisti C., 2008 - An invaded wet ecosystem in Central Italy: an arrangement and evidence for an alien food chain. Atti della Accademia nazionale dei Lincei. Rendiconti Lincei. Matematica e applicazioni Accademia nazionale dei Lincei, 19: 161-171.

Angelici C., Marini F., Battisti C., Bertolino S., Capizzi D. \& Monaco A., 2012 - Cumulative impact of rats and coypu on nesting waterbirds: first evidences from a small Mediterranean wetland (central Italy). Vie et Milieu, 62: 137-141.

Angelici C. \& Brunelli M., 2012 - Year-round use of the Regional Nature Reserve of Nazzano, Tevere-Farfa (Latium, central Italy) by waterbirds. Avocetta, 36: 113-120.

Arena S., Battisti C., \& Carpaneto G.M., 2011 - The ecological importance of wetlands for aerial insectivores (swifts, martins and swallows) along the Tyrrhenian coast. Atti della Accademia nazionale dei Lincei. Rendiconti Lincei. Matematica e applicazioni Accademia nazionale dei Lincei, 22: 395-402.

Barrett G.W., Van Dyne G.M. \& Odum E.P., 1976 - Stress ecology. BioScience, 26: 192-194.

Battisti C., 2006. Biodiversità, gestione, conservazione di un'area umida del litorale tirrenico: la Palude di Torre Flavia. Gangemi editore, Roma.

Battisti C., Sorace A., De Angelis E., Galimberti C. \& Trucchia N., 2004 - Waterbird abundance in a residual wetland of Central Italy during two years of contrasting water level. Avocetta, 28: 86-90.

Battisti C., Aglitti C., Sorace A. \& Trotta M., 2006 - Water level and its effect on the breeding bird community in a remnant wetland in Central Italy. Ekologia, Bratislava, 25: 252-263.

Battisti C., Luiselli L., Pantano D. \& Teofili C., 2008 - On threats analysis approach applied to a Mediterranean remnant wetland: Is the assessment of human-induced threats related into different level of expertise of respondents? Biodiversity and Conservation, 16: 15291542.

Battisti C., Dodaro G. \& Franco D., 2014 - The data reliability in ecological research: a proposal for a quick selfassessment tool. Natural History Science, 1: 75-79.

Benassi G., Battisti C., Luiselli L. \& Boitani L., 2009 Area-sensitivity of three reed bed bird species breeding in Mediterranean marshland fragments. Wetland Ecology and Management, 17: 555-564.
Bibby C.J. \& Burgess N.D., 1992 - Bird Census Techniques. Academic Press, London.

Biondi M., Guerrieri G. \& Pietrelli L., 1990 - Ciclo annuale della comunità ornitica di una zona umida artificiale dell'Italia centrale. Avocetta, 14: 11-26.

BirdLife International 2004 - Birds in Europe: population estimates, trends and conservation status - BirdLife Conservation Series No.12, BirdLife International, Cambridge.

Blasi C. \& Michetti L., 2005 - Biodiversità e Clima. In: Stato della biodiversità in Italia, Contributo alla strategia nazionale per la biodiversità. Blasi C., Boitani L., La Posta S., Manes F., Marchetti M. (eds.). Ministero dell'Ambiente e della Tutela del territorio, Fratelli Palombi editori, Roma: 57-66.

Blondel J. \& Aronson J., 1999 - Biology and wildlife of the Mediterranean Region. University Press, Oxford.

Brawn J.D., Robinson S.K. \& Thompson F.R., 2001 The role of disturbance in the ecology and conservation of birds. Annual Review Ecology and Systematic, 32: 251-276.

Brönmark C. \& Hansson L.A., 2005 - The Biology of Lakes and Ponds, $2^{\text {nd }}$ edition. Oxford University Press, New York, Oxford.

Brown J.H. \& Kodric-Brown A., 1977 - Turnover rates in insular biogeography: effect of immigration on extinction. Ecology, 58: 445-449.

Celada C. \& Bogliani G., 1993 - Breeding bird communities in fragmented wetlands. Bollettino di Zoologia, 60: 73-80.

Cowardin L.M., Carter V., Golet F.G. \& Laroe E.T., 1979 - Classification of wetlands and deepwater habitats of the United States. FWS/OBS-79/31 - Fish and Wildlife Service, USDI.

Debinski D.M. \& Holt R.D., 2000 - A survey and overview of habitat fragmentation experiments. Conservation Biology, 14: 342-355.

Dornelas M., Soykan C.U. \& Ugland K.I., 2011 - Biodiversity and disturbance. In: Biological diversity. Frontiers in measurements and assessments. Magurran A., McGill B.J. (eds.), Oxford University press, Oxford: 237-251.

Dytham C., 2011 - Choosing and using statistic. A Biologist's guide. Wiley-Blackwell, London.

Finlayson C.M. (ed.), 1992 - Integrated management and conservation of wetland in agricultural and forested landscapes. IWRB Special Publication, Slimbridge, 22.

Gillings S., Fuller R.J. \& Sutherland W.J., 2005 - Diurnal studies do not predict nocturnal habitat choice and site selection of European golden-plovers (Pluvialis apricaria) and northern lapwings (Vanellus vanellus). Auk, 122: $1249-1260$.

Goutner V., Kazantzidis S. \& Charalambidou I., 2005 Patterns of occurrence of waders (Aves, Charadrii) in the Axios Delta, Macedonia, Greece. Journal of Biological Research, 3: 47-58.

Hobbs R.J. \& Huenneke L.F., 1992 - Disturbance, diversity and invasions: implications for conservations. Conservation Biology, 6: 324-337. 
Kirby J.S., 1997 - Influence of environmental factors on the numbers and activity of wintering Lapwings and Golden Plowers. Bird Study, 44: 97-110.

Lourenço P.M., Silva A., Santos C.D., Miranda A.C., Granadeiro J.P. \& Palmeirim J.M., 2008 - The energetic importance of night foraging for waders wintering in a temperate estuary. Acta Oecologica, 34:122-129.

Magurran A., 2004 - Measuring biological diversity. Blackwell Publishing, Malden.

Magurran A. \& McGill B.J., 2011 - Biological diversity. Frontiers in measurements and assessments. Oxford University press, Oxford.

Martìnez-Vilalta J., Bertolero A., Bigas D., Paquet J.Y. \& Martìnez-VilaltaA., 2002-Habitat selection of passerine birds nesting in the Ebro Delta reed beds (NE Spain): management implications. Wetlands, 22: 318-325.

Mitsch W.J. \& Gosselink J.G., 2000 - Wetlands, III ed. Wiley Inc.; New York.

Nankinov D., Tsvetkova K., Bedev K., Lamburov G., Minchev N., Bozhilov V. Marin S., Seizov G. \& Kotsakov G. 1996 - A census of migrating waders in Bulgaria during March-May 1990. Wader Study Group Bulletin, 83: 37-43.

Petraitis P.S., Latham R.E. \& Niesenbaum R.A., 1989 The maintenance of species diversity by disturbance. Quarterly Review Biology, 64: 393-418.

Poulin B., Lefebvre A. \& Mauchamp A., 2002 - Habitat requirements of passerines and reed bed management in southern France. Biological Conservation, 107: 315-325.

Redolfi De Zan L., Battisti C. \& Carpaneto G.M., 2011 Inter-annual and intra-seasonal patterns of abundance in a set of common waterbirds: along term study in a Mediterranean wetland. Vie et Milieu, 61: 101-106.

Ryan P.G., 2013 - Medium-term changes in coastal bird communities in the Western Cape, South Africa. Australian Ecology, 38: 251-259.

Santoro R., Jucker T., Prisco I., Carboni M., Battisti C. \& Acosta T.R., 2012 - Effect of trampling limitation on coastal dune plant communities. Environmental Management, 49: 534-542.

Scarton F., Cecconi G., Cerasuolo C. \& Valle R., 2013 The importance of dredge islands for breeding waterbirds. A three-year study in the Venice Lagoon (Italy). Ecological Engineering, 54: 39-48.

Saunders D.A. \& Derebeira C.P., 1986 - Seasonal occurrence of members of the suborder Charadrii (waders or shorebirds) on Rottnest Island, Western-Australia. Australian Wildlife Research, 13: 225-244.

Serra L., Casini L., Della Toffola M., Magnani A., Meschini A. \& Tinarelli R., 1992 - Results of a survey on wader spring migration in Italy (March-May1990). Wader Study Group Bulletin, 66: 54-60.

Shannon C.E. \& Weaver W., 1963 - Mathematical theory of communication. University of Illinois Press, Urbana.

Shrubb M., 2007 - The lapwing. $T$ and AD Poyser, London.

Sousa W., 1984 - The role of disturbance in natural communities. Annual Review of Ecology, Evolution and Systematics, 15: 353-391.
SPSS Inc., 2006 - SPSS for Windows (Version 15.0). SPSS Inc, Chicago.

Tomaselli R., Balduzzi A. \& Filippello S., 1973 - Carta Bioclimatica d'Italia. Collana verde, 33. Ministero Agricoltura e Foreste, Roma.

Trotta M., 2012 - Successo alimentare e attività di vigilanza della Pavoncella Vanellus vanellus nei pascoli costieri del Parco Nazionale del Circeo (Lazio, Italia centrale). Avocetta, 36: 75-79.

Walk A.G. van der, 2006 - The biology of freshwater wetlands. Oxford University Press, Oxford.

Zacchei D., Battisti C. \& Carpaneto G.M., 2011 - Contrasting effects of water stress on wetland-obligated birds in a semi-natural Mediterranean wetland. Lakes and Reservoirs: Research and Management, 16: 281-286. 